\title{
Anti-inflammatory and analgesic potential of hydrolyzed extract of Agave sisalana Perrine ex Engelm., Asparagaceae
}

\author{
Ricardo J. Dunder, ${ }^{* 1}$ Ana E. V. Quaglio, ${ }^{2}$ Rubens P. Maciel, ${ }^{2}$ Anderson Luiz-Ferreira, ${ }^{1}$ \\ Ana C. A. Almeida, ${ }^{1}$ Christiane Takayama, ${ }^{1}$ Felipe M. de Faria, ${ }^{1}$ Alba R. M. Souza-Brito ${ }^{1}$
}
${ }^{1}$ Laboratório de Produtos Naturais, Universidade Estadual de Campinas, Departamento de Fisiologia e Biofísica, Instituto de Biologia Rua Monteiro Lobato s/n Caixa Postal 6109, 13.083-970 Campinas-SP, Brazil,
${ }^{2}$ Universidade Estadual de São Paulo, Campus de Assis, Departamento de Biologia, Avenida Dom Antonio, 2100, 19806-900 Assis-SP, Brazil.

\begin{abstract}
RESUMO: "Potencial anti-inflamatório e analgésico do extrato hidrolisado de Agave sisalana Perrine ex Engelm, Asparagaceae." As propriedades hemolítica, anti-inflamatória e antinociceptiva do extrato hidrolisado de Agave sisalana Perrine ex Engelm, Aparagaceae (HEAS) foram avaliadas em modelos clássicos de inflamação. Camundongos Swiss e ratos Wistars machos receberam HEAS $(500 \mathrm{mg} / \mathrm{kg})$ em duas vias de administração p.o e i.p em solução salina $0.9 \%$. A hidrólise ácida inibiu a ação hemolítica das saponinas através da retirada das cadeias laterais de açúcar. O tratamento com HEAS reduziu significativamente o edema de orelha induzido por xilol em duas vias $13 \pm 1.5$ e $10 \pm 0.63 \mathrm{mg}$ respectivamente, $p . o$ e $i . p$, em comparação com os controles $27 \pm 1.5$ salina e $13.5 \pm 1.2$ AAS. O HEAS também diminuiu o edema induzido por carragenina $43 \pm 1.58 \mathrm{mg}$ (p.o) e $17 \pm 1.26 \mathrm{mg}$ (i.p), quando comparado com os grupos controle $52 \pm 1.58$ (salina) e $10.05 \pm 1.58$ (indometacina). HEAS apresentou efeito analgésico em modelo de contorções abdominais $30.7 \%$ (p.o), 88.7\% (i.p) comparado com aquele produzido pelo (AAS) 70.6\%. Contudo, no modelo crônico de inflamação granuloma cotton pellet apenas a via i.p diminuiu o tecido granulomatoso (20.4 $\pm 1.32 \mathrm{mg}$ ) comparado com os controles $30.5 \pm 2.53$ (salina) e $20.2 \pm 2.18 \mathrm{mg}$ (dexametasona). Esses dados sugerem que o HEAS possui atividades anti-inflamatória e analgésica em processos agudos e crônicos.
\end{abstract}

Unitermos: Agave sisalana, Asparagaceae, Agavoideae, hemolítica anti-inflamatória, analgesia.

\begin{abstract}
The hemolytic, anti-inflammatory and antinociceptive properties from hydrolyzed extract Agave sisalana Perrine ex Engelm., Asparagaceae (HEAS) was evaluated on classic inflammation models. Male Swiss mice and male Wistars rats received HEAS $(500 \mathrm{mg} / \mathrm{kg})$ in two administration p.o. and i.p. in saline solution $0.9 \%$. The acid hydrolysis inhibited the hemolytic action of saponins due to the retreat of side chain sugar. The treatment of the ear induced oedema by xylene with HEAS significantly reduced in two routes $13 \pm 1.5$ and $10 \pm 0.63 \mathrm{mg}$, respectively, p.o. and i.p., in comparison with controls $27 \pm 1.5$ saline and 13.5 \pm 1.2 AAS. The HEAS also diminished edema induced by carrageenin $43 \pm 1.58 \mathrm{mg}$ (p.o.) and $17 \pm 1.26 \mathrm{mg}$ (i.p.), when compared with control groups $52 \pm 1.58 \mathrm{mg}$ (saline) and $10.05 \pm 1.58$ (indomethacin). HEAS showed analgesic effects in abdominal constrictions $30.7 \%$ (p.o.), $88.7 \%$ (i.p.) comparable to that produced by (AAS) $70.6 \%$. However in granuloma cotton pellet a chronic model of inflammation just the i.p. pathway decreased granulomatous tissue $(20.4 \pm 1.32 \mathrm{mg}$ ) compared with controls $30.5 \pm 2.53 \mathrm{mg}$ (saline) and $20.2 \pm 2.18 \mathrm{mg}$ (dexamethasone). These data suggest that HEAS has anti-inflammatory and analgesic activity on acute and chronic processes.
\end{abstract}

Keywords: Agave sisalana, Asparagaceae Agavoideae, hemolytic, anti-inflammatory, analgesic.

\section{INTRODUCTION}

Inflammation is a host response against microorganisms or tissue injury. The problem begins when inflammation turn into a chronic process, for example, rheumatoid arthrits is characterized by the accumulation and persistence of inflammatory cells in sinovial joints, which results in joint damage, other diseases like chronic bronchitis and ulcerative colitis also are a kind inflammation (Lawrence et al., 2002). This problem is characterized by a reaction that promotes a local vasodilatation, increases a regional flow to the inflamed area, and together with an intensive microvascular permeability, results in five cardinal signs: heat, redness, swelling, pain and loss of 
function (Gilroy et al., 2004).

During the inflammation, various proinflammatory cytokines such as tumour necrosis factor and interleukin that activate signaling pathways in endotelial cells regulate the expression of enzimes and prostanoids (Flower, 2006). Essentially, in humans cell membranes glycerophospholipids suffer hydrolyze the sn-2 ester bond promoted by the phospholipase A2 (PLA $)$ that results in fatty acids, particularly arachidonic acid (AA) (Yedgar et al., 2006). After this, AA is catalyzed in prostaglandin E2 $\left(\mathrm{PGE}_{2}\right)$ by ciclooxigenase-2 (COX-2) enzyme. $\mathrm{PGE}_{2}$ is involved in pain and fever (Kummer \& Coelho 2002).

For a treatment against inflammation the first drug choice is a non steroidals antiinflammatory drugs (NSAIDS), for example salicylates (salycilic acid), profens (ibuprofen) and arylalkanoic acids (indomethacin) (Flower et al., 1972).

Generally the NSAIDS inhibit the production of PGE2 by blocking the COX-2 enzyme causing analgesic and antiinflammatory effects. However NSAIDS bring a side effect like a gastroduodenal toxicity, through inhibition of COX-1. NSAIDS may reduce specific prostaglandin, this prostaglandin is very important in the defense of gastric mucosa, because it is a compound of the mucous layer of the stomach interior (Vonkeman \& Van de Laar 2008). Another way is glucocorticoids drugs such as dexamethasone, these anti-inflammatory drugs inhibit the $\mathrm{PLA}_{2}$ (Little et al., 1999) or act against activation of NF$қ B$ this is correlated with the increase of genes encoding inflammatory process (Barnes, 2006)

Phytoterapy is an alternative for inflammation control; different species of plants are used in folk medicine. Around the world, different Agave species play an important role on inflammation process (Tyler et al., 1988), for example Agave intermixta trel is used in the treatment of inflammatory arthritis and tumors (Garcia et al., 1999), in other studies Peana e colaboradores (1997) showed the anti-inflammatory potential of $A$. americana in i.p. route.

The genus Agave constitutes an important source of steroidal sapogenins, these compounds are used for the semisynthesis of corticosteroids (Ferreira da Silva \& Beltrão, 1999).

Agave sisalana is a plant belonging to Asparagaceae family. It is an extensively cultivated species around the world, in tropical and subtropical zones (Oashi, 1999). This plant is a very important resource of hard fiber and its juice is very saponin-rich, necessary to the obtaining of steroidal material (Ding et al., 1989). But these saponins have hemolytic activity due to their side sugar chains. It is necessary to make an acid hydrolysis to remove the side sugar chains (Oda et al., 2000).

In according to results from other plants of Agave genus, we have evaluated the chemical hydrolysis and its efficacy to remove the sugar chain. We have also investigated the antinociceptive and antiinflammatory action of hydrolised extract of $A$. sisalana (HEAS) on a single dose of $500 \mathrm{mg} / \mathrm{kg}$ in two routes (p.o. and i.p.).

\section{MATERIAL AND METHODS}

\section{Drugs}

Acetic acid, xylene (Merck, Brazil), dexamethasone (Hoechst S.A., Brazil), carraggenin and indomethacin (Sigma Chemical Co., St Louis, Mo), acetyl salicilic acid (Bayern., Brazil) were used in this study. All drugs and extracts were dissolved in $0.9 \% \mathrm{NaCl}$ solution just before use. All reagents used were of high grade of purity.

\section{Animals}

The experiments were performed on male Swiss mice $(30 \pm 5 \mathrm{~g})$ and male Wistar rats $(180 \pm 30 \mathrm{~g})$ obtained from de animal house of CEMIB/UNICAMP, Campinas, SP. The animals were fed a certified Nuvilab CR-a (Nuvital) diet with free acces to tap water and were housed on 12-h light: 12 -h dark cycles at $50 \%$ humidity and temperature of $24 \pm 1{ }^{\circ} \mathrm{C}$. The experimental protocols were approved by Animal Use and Care Comittee of Unicamp (protocol number: 1281-1)

\section{Plant Material}

The Agave sisalana Perrine ex Engelm., Asparagaceae, was cultived, in "Riacho do Cedro", farm located in the city of Santo Domingo in Bahia state. The botanical identification was performed by Dr. Jorge Tamashiro, and a voucher specimen was deposited at the herbarium of the State University of Campinas, (Voucher UEC: 150.429). The leaves were crushed to get the fiber and separate the juice. A. sisalana unmanufactured juice was donated by "Corona Comércio e Indústria LTDA" situated in Salvador-Bahia.

\section{Extract preparation}

HEAS was obtained through A. sisalana unmanufactured juice. This juice suffered a heating of $100{ }^{\circ} \mathrm{C}$ that increased its concentration by ten times. The consistence of the juice was similar to a caramel, which was named crude extract (CE). After heated the CE (40 g) suffered an acid hydrolyses with $2 \mathrm{~N} \mathrm{HCl}(300 \mathrm{~mL})$ at reflux temperature for $4 \mathrm{~h}$ in agitation. The dark precipitate which was formed was separated from the acid solution by filtering after cooling the suspension at room temperature. The dark precipitate is a HEAS.

\section{Hemolytic activity}

The hemolytic activity of HEAS was measured 
according to the method of Sun (2006), with some modifications. Aliquots of $5 \mathrm{~mL}$ of Wistar rats blood were washed with sterile saline solution $0.9 \%$ by centrifugation at $180 \mathrm{x} \mathrm{g}$ for $5 \mathrm{~min}$. The cell suspension was finally prepared with the pellet with $2 \%$ in saline solution. The 2 $\mathrm{mL}$ volume of the cell suspension was mixed with $2.0 \mathrm{~mL}$ of diluents containing 100,50,25, 12.5, 6.25 and $3.12 \mu \mathrm{g} /$ $\mathrm{mL}$ concentrations of the crude extract (CE) and HEAS. The mixtures were incubated for $30 \mathrm{~min}$ at $37{ }^{\circ} \mathrm{C}$ and centrifugated at $70 \mathrm{x}$ g for $10 \mathrm{~min}$. The free haemoglobin in the supernatants was measured spectophotometrically at $540 \mathrm{~nm}$. The non isotonized saline and extracts, were included as minimal and maximal hemolytic control. The experiments were carried in triplicate.

\section{Xylene-induced ear edema in mice.}

The method described by Young and De Young (1989) was employed. Male Swiss mice were divided in four groups $(\mathrm{n}=8)$. Negative control (saline solution), positive control (AAS, $10 \mathrm{mg} / \mathrm{kg}$ ) and other two groups received HEAS $(500 \mathrm{mg} / \mathrm{kg}$ p.o. and i.p.). The groups received the drugs and one hour after, $0.03 \mathrm{~mL}$ xylene was applied to the anterior and posterior surfaces of the left ear. The right ear was considered as the control. One hour after the xylene application, the mice were killed by cervical dislocation and $8 \mathrm{~mm}$ punches were made in the left and right ear by a borer. Each ear disc was weighed and the differences in weight of the left and the right ear discs were measured as the edema level.

\section{Carrageenin-induced paw edema in mice}

The method used was similar to that described by Henriques et al., (1987), using groups of male mice $(\mathrm{n}=8)$. Indomethacin $(5 \mathrm{mg} / \mathrm{kg}$, p.o. $)$ was used as positive control and pre treatment with HEAS $(500 \mathrm{mg} / \mathrm{kg}$ p.o. or i.p.) was administered $1 \mathrm{~h}$ before the injection of $0.2 \mathrm{~mL}$ of carrageenin $(1 \% \mathrm{w} / \mathrm{v}$ in saline solution) into the subplantar region of the mice left hind paw. The paw volume was measured $4 \mathrm{~h}$ after carrageenin injection. The increase in weight caused by the flogistic agent was calculated by subtracting the weight of the untreated left paw from that of the treated right paw.

\section{Abdominal writhing caused by intraperitoneal injection of acetic acid.}

The response to intraperitoneal injection of a $0.6 \%$ acetic acid solution, a contraction of the abdominal muscle and stretching of the hind limbs, were induced according to procedure described by Koster et al (1959). Animals $(\mathrm{n}=8)$ were pretreated with HEAS $(500 \mathrm{mg} / \mathrm{kg}$ p.o. or i.p. $)$ and negative control received a similar volume of $0.9 \% \mathrm{NaCl}$ solution. Positive control mice received AAS. The drugs were administered $1 \mathrm{~h}$ before of $0.6 \%$ acetic acid. After induction, pairs of mice were placed in separate transparent boxes and the number of the abdominal writhes were counted over a period from 6 to $21 \mathrm{~min}$. Antinociceptive activity was expressed as the reduction of the number of abdominal writhes.

\section{Granuloma cotton pellet in rats}

Groups of Wistar rats $(\mathrm{n}=6)$ were used to determine the effects of the HEAS $(500 \mathrm{mg} / \mathrm{kg}$ p.o. and i.p.) on the proliferative phase of granuloma (the dry weight of the pellet seven days after treatment) according to the method of Swingle \& Shideman (1972). Dental cotton rolls (Johnson \& Johnson) were cut into $20 \mathrm{mg}$ pellets which were sterelized an implanted subcutaneously into the dorsal region of the rats. The animals were orally treated with saline $0.9 \%$; Dexamethasone $0.10 \mathrm{mg} / \mathrm{kg}$ p.o. was used as a standard reference drug. The animals were treated daily during seven days, on the 8 th day, they were killed by cervical dislocation and the granulomatous tissues were removed. The pellets were dried overnight at $60{ }^{\circ} \mathrm{C}$ and the granulomas were weighed. The difference between the final and initial weights was regarded as the graulomatous tissue produced.

\section{Statistical analysis}

Data are reported as mean \pm SEM. The statistical analyses were carried out using the one way anova follow the specific Bon Ferroni test, for significant values $p<0,05$. The statistical analysis was made by Graph pad PRISMA 5.0 software.

Table 1. Hemolytic percent of extracts (CE and HEAS) of Agave sisalana.

\begin{tabular}{ccc}
\hline Group $(\mu \mathrm{g} / \mathrm{mL})$ & Absorbance & Hemolytic (\%) \\
\hline Without isotonic $^{*}$ & 1.569 & 100 \\
Saline $^{*}$ & 0.187 & \\
CE 100 & $1.361 \pm 0.01$ & 86.7 \\
CE 50 & $1.527 \pm 0.03$ & 97.3 \\
CE 25 & $1.607 \pm 0.02$ & 102.0 \\
CE 12.5 & $1.522 \pm 0,02$ & 97.0 \\
CE 6.25 & $0.931 \pm 0.01$ & 59.3 \\
CE 3.12 & $0.632 \pm 0.08$ & 40.3 \\
HEAS 100 & $1.095 \pm 0.02$ & 69.8 \\
HEAS 50 & $1.092 \pm 0.18$ & 69.6 \\
HEAS 25 & $0.237 \pm 0.08$ & 15.1 \\
HEAS 12.5 & $0.156 \pm 0.02$ & 9.9 \\
HEAS 6.25 & $0.136 \pm 0.02$ & 8.6 \\
HEAS 3.12 & $0.109 \pm 0.01$ & 6.9 \\
\hline
\end{tabular}

*Hemolytic percent of saline and extract non isotonic were included as minimal and maximal hemolytic control. All values represent the mean $\pm \mathrm{SEM}$. 
Table 2. Effects of HEAS on acetic acid-induced abdominal writhing in mice.

\begin{tabular}{ccc}
\hline Groups & Number of Writhing & Inhibition (\%) \\
\hline Saline & $52 \pm 1.26$ & - \\
AAS & $15.3 \pm 1.58^{* * *}$ & 70.6 \\
$500 \mathrm{mg}$ p.o. & $36 \pm 1.26^{* * *}$ & 30.7 \\
$500 \mathrm{mg}$ i.p. & $6 \pm 0.63^{* * *}$ & 88.7 \\
\hline
\end{tabular}

Each value is the mean+SEM for eight animals. Significantly different compared to the respective controls. Anova follow Bon Ferroni test $\left({ }^{* * *} \mathrm{p}<0.0001\right)$.

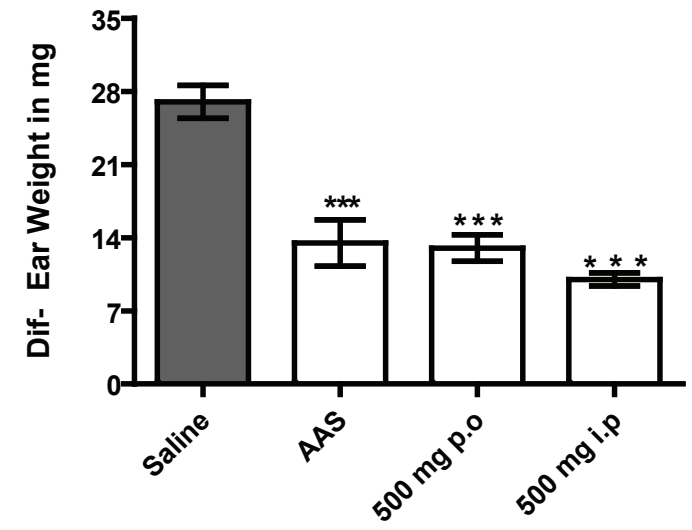

Figure 1. Effect of HEAS (p.o. and i.p.) and AAS p.o in the ear edema induced by xylene. *ANOVA followed by Bon ferroni test, with $p<0.0001$. Data was expressed as media+SEM. $\mathrm{n}=8$ group.

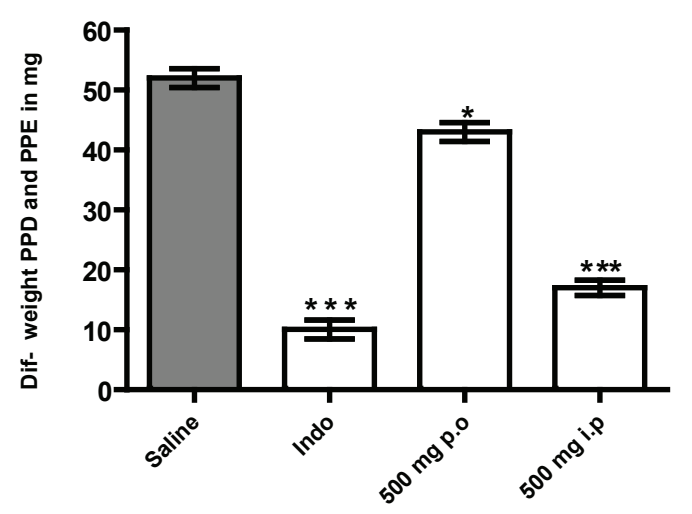

Figure 2. Effect of HEAS (p.o. and i.p.) and indomethacin p.o in the hind paw edema induced by carragenin. *ANOVA followed by Bon ferroni test, with ${ }^{*} p<0.05$ and $p<0.0001$. Data was expressed as media+SEM. $\mathrm{n}=8$ group.

\section{RESULTS}

\section{Haemolytic activities}

The haemolytic activity of HEAS on rat red blood cells was showed in Table 1 . The HEAS showed a reduction value of haemolytic percent in interval $69.8 \%$ to $6.9 \%$ whereas the CE showed values on interval between $102 \%$ up to $40 \%$.

\section{Xylene induced ear edema}

Effects of HEAS on xylene induced ear edema in mice. The administration of HEAS in p.o. and i.p. significantly $(p<0.0001)$ suppressed xylene-induced ear edema in mice (Figure 1). The antiedematogenic potential was presented by differences in ear weight. HEAS was ${ }^{* * *} 13 \pm 1.5$ and ${ }^{* * *} 10 \pm 0.63 \mathrm{mg}$ respectively p.o. and i.p., the controls presented $\left(27 \pm 1.5\right.$ saline and ${ }^{* * *} 13.5 \pm 1.2$ AAS $)$.

\section{Hind paw edema}

In the assay induced by carrageenin, the treatment with $500 \mathrm{mg} / \mathrm{kg}$ of HEAS, either administrations (p.o. and i.p.) produced statistically significant reduction of edema when compared with control $(p<0.05$ and $p<0.0001)$, as show in Figure 2 . The statistical values were $\left({ }^{*} 43 \pm 1.58\right.$ and $\left.{ }^{* * *} 17 \pm 1.26 \mathrm{mg}\right)$, in relation to controls $(52 \pm 1.58$ saline and *** $10.05 \pm 1.58 \mathrm{mg}$ indometacin).

\section{Abdominal writhing}

To verify the possible analgesic effect of HEAS, we used these test of pain induction. Our results showed that both administrations of HEAS inhibited acid-induction constriction in mice $(p<0.0001)$, as can be seen from Table 2 . The inhibition percentage presented values of $30.7 \%$ p.o. and $88.7 \%$ i.p.; the control presented $70.6 \%$ of inhibition.

\section{Cotton pellet}

The effects of HEAS and dexamethasone on cotton pellet granuloma in rats are showed in graphic in Figure 3. In these assays just HEAS i.p. as well dexamethasone inhibit significantly $(p<0.05)$ granuloma formation compared with the saline group. HEAS i.p. exhibited values of $(23.3 \pm 3.17$ and $* 20.4 \pm 1.32 \mathrm{mg})$ related with controls $(30.5 \pm 2.53 \mathrm{mg}$ saline and $* 20.2 \pm 2.18$ dexamethasone).

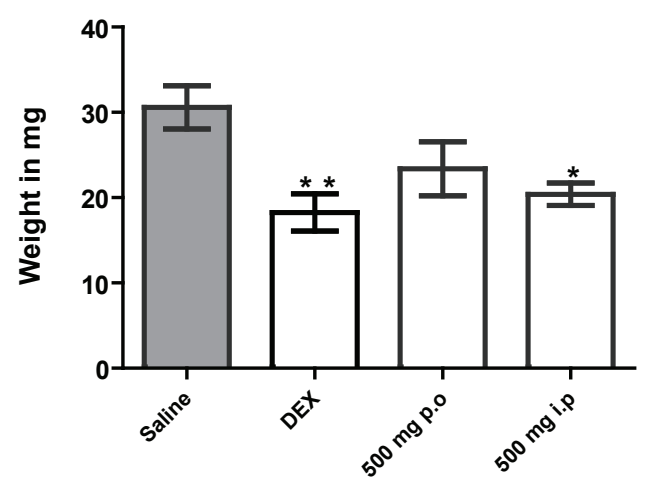

Figure 3. Effect of HEAS $500 \mathrm{mg} / \mathrm{kg}$ p.o and i.p administration and dexamethasone $(0.10 \mathrm{mg} / \mathrm{kg}$ p.o $)$ in granulomatous tissue formation *ANOVA followed Bon ferroni test ${ }^{* *} p<0.01$ an ${ }^{*} p<0.05$. Data are expressed as media $+\mathrm{SEM} \mathrm{n}=6$ group. 


\section{DISCUSSION}

Plants of genus Agave have been distributed around the World and some species have been used worldwide to treat pain and inflammation. These antiinflammatory properties are attributed to steroidal saponins present as the major constituents in extracts of this plant (Lacaille-Dubois \&Wagner, 1996).

The hemolytic activities of saponins are related to their chemical composition. This assay indicates that the acid hydrolyses of CE was effective, since that HEAS extract counting sapogenins showed minor hemolytic percentage (69.9 maximum) in comparison to $\mathrm{CE}$ (102 maximum) which is very rich in saponins. Santos et al., 1997 reported that steroidal saponins of $A$. sisalana were more hemolytic in comparison with triterpenoid saponins. However in our research, we have made an acid hydrolysis aiming to reduce hemolytic action by the removal of glicosidic moiety. Another plant $A$. attenuata after acid hydrolysis showed an absence of haemolytic effects, this behavior can be explained by aglycone that misses anphipathic features (Da Silva et al., 2002).

The anti-inflammatory activity of HEAS in acute inflammations was evaluated by xylene-induced mouse ear edema model. The results indicated that HEAS had a substantial effect in reducing the xylene-induced edema, probably because of the reduction of permeability. Other assays, hind paw edema corroborated with the xylene test, decreasing the paw edema induced by carrageenin in two administrations (p.o. and i.p.) as compared with the respective control values. The technique developed by Henriques e colaboradores (1987) is a classic model to evaluate specific acute inflammation model in mice, that involves various types of chemical mediators of inflammation such as histamine, serotonin, bradykinin and prostaglandins (Winter et al., 1962). Peana e colaboradores (1997) showed that steroidal sapogenins (hecogenin and tigogenin) presented anti-inflammatory action comparable to that of dexamethasone. Most likely, the presence of the same sapogenins in HEAS, are responsible for this activity.

The antinociceptive effects of HEAS on the abdominal writhes showed the inibition of the painful stimulation by $30.7 \%$ and $88.7 \%$ (p.o. and i.p.) compared to those of control values. However this antinociceptive model it is a non selective model, consequently opioids drugs or NSAIDS inhibit pain in this model (Bighetti et al., 1999) the acetic acid acts indirectly by releasing endogenous mediators like prostaglandins that stimulate nociceptive neurons sensitive to NSAIDS and centrally active drugs. In the research, the results suggest that the antinociceptive activity is related to the anti-inflammatory potential of steroidals sapogenins.

A cronic inflammatory model, granuloma cotton pellet is divided in three phases, 1. transudative, 2. an exudative and 3. proliferative phase. Glucocorticoids like dexamethasone inhibit lymphocyte infiltration and skin fibroblast growth rate (Gepdiremen et al., 2004). In this test we investigated the granulomatous process in a cronic inflammation model, but just the administration i.p. was statistically significant, meanwhile i.p. way showed values comparative to dexamethasone, this suggests that the antiinflammatory potential of steroidal sapogenins may be related to its molecule architecture, which is similar to the structure of glucocorticoids.

Apparently, HEAS has a pharmacokinetic factor because the administration i.p. is more effective than p.o. application (Gilman et al., 2001). Yoshiki et al., 2005 did test in vivo with saponins in different routes and suggested that saponins are not absorbed in the gastrointestinal tract due to the enzymatic action.

In conclusion, those previous studies with HEAS showed the acid hydrolysis reducing hemolytic potential of steroidal saponins in A. sisalana and showed antiinflammatory and antinociceptive activity, through two ways of application. These results suggest that new tests with a purer fraction should be carried out in order to assess the mechanisms of action of the steroidal saponins.

\section{ACKNOWLEDGMENTS}

The authors are grateful of Dr. Pedro Oliva Neto (University Julio Mesquita Filho, Assis Campus) for a Sisal extracts and to FAPESP, CNPq and CAPES. In memoriam of Juliano Souza Gracioso, amazing teacher is an example of great profissional in pharmaceutical sciences.

\section{REFERENCES}

Barnes JP, 2006. How corticosteroids control inflammation: Quintiles Prize Lecture 2005. Brit J Pharmacol 148: 245-254.

Bighetti EJ, Hiruma-Lima CA, Gracioso JS, Brito ARMS 1999. Anti-inflammatory and antinociceptive effects in rodents of the essential oil of Croton cajucara Benth. J Pharm Pharmacol 51: 1447-1453.

Da Silva BP, De Sousa AC, Silva GM, Mandes TP, Parente JP 2002. A new bioactive steroidal saponin from Agave attenuata. Z. Naturforsch C 57: 423-428.

Ding Y, Chen YY, Wang DZ, Yang CR 1989. Steroidal saponins from a cultivated form of Agave salana. Phytochemistry 28: 2787-2791

Ferreira da Silva ORR, Macedo Beltrão NE 1999. O agronegócio de sisal no Brasil , $1^{\circ}$ Ed. Embrapa: Campina Grande-PB, p. 25.

Flower R, Gryglewski, Herbaczynska-Cedro K, Vane JR 1972. Effects of anti-inflammatory drugs on prostaglandins biosynthesis. Nat New Biol 238: 104-106.

Flower RJ 2006. Prostaglandins, bioassay and inflammation. Brit J Pharmacol 147: 182-192.

Garcia MD, Quilez AM, Saenz MT, Martinez-Dominguez ME 1999. Anti- inflammatory activity of Agave intermixta Trel and Cissus sicyoides L., species used in the Caribbean traditional medicine. J Ethnopharmacol 71: 395-400.

Gepdiremen A, Mshvildadze V, Süleyman H, Elias R 2004. Acute 
and chronic antiinflammatory effects of Hedera colchica in rats. J Etnopharmacol 94: 191-195.

Gilman GA, Goodman LS, Rall TW, Murad F 2001 Goodman and Gilman's Pharmacological Basis of Therapeutics $8^{\text {th }}$ Ed., MacMillan, New York.

Gilroy DW, Newson J, Sawmynaden P, Willoughby DA, Croxtall JD 2004. A novel role for phospholipase A2 isoforms in the checkpoint control of acute inflammation. FASEB $J$ 18: 489-498.

Henriques MGMO, Silva PMR, Martins MA, Flores CA, Cunha FQ, Assreuy-Filho J, Cordeiro RSB 1987. Mouse paw edema. A new model for inflammation. Braz J Med Biol Res 20: 243-249.

Koster R, Anderson M, De Beer EJ 1959. Acetic acid for analgesic screening. Fed Proc 18: 412-418.

Kummer CL, Coelho TC 2002. Antiinflamatórios não esteróides inibidores da ciclooxigenase-2 (COX-2): Aspectos atuais. Rev Bras Anestesiol 52: 498-512.

Lacaille-Dubois MA, Wagner H 1996. A review of the biological and pharmacological acivities of saponins. Phytomedicine 2: 363-386.

Lawrence T, Willoughby DA, Gilroy DW 2002. Antiinflammatory lipid mediators and insights into the resolution of inflammation. Nat Rev 2: 787-795.

Little RJ, Bodor N, Loftsson T 1999. Soft drugs based on hydrocortisone: the inactive metabolite approach and its application to steroidal agents. Pharm Res 16: 961-967.

Oda K, Matsuda H, Murakami T, Katayama S, Ogitani T, Yoshikawa M. 2000. Adjuvant and haemolytic activies of 47 saponins derived from medicinal and food plants. Biol Chem 381: 67-74.

Oashi MC 1999. Estudo da cadeia produtiva como subsídio para pesquisa e desenvolvimento do agronegócio do sisal na Paraíba. Tese de Doutorado, Universidade Federal de Santa Catarina, 1999.

Peana AT, Moretti MD, Manconi V, Desole G, Pippia P 1997. Anti-inflammatory activity of aqueous extracts and steroidal sapogenins of Agave americana. Planta Med 63: 199-202.

Santos WR, Bernardo RR, Peçanha LM, Palatnick M, Parente JP, Palatnick CS 1997. Hemolytic activities of plants saponins and adjuvants. Effects of Periantra mediterranea saponin on the humoral response to the FML antigen of Leismania donovani. Vaccine 15: 1024-1029.

Sun HX 2006. Hemolytic activities and adjuvants effect of Bupleurum chinese saponins on the immune responses to ovoalbumin in mices. Vaccine 24: 1324-1331.

Swingle KF, Shideman FE 1972. Phases of the inflammatory response to subcutaneous implantation of cotton pellet and their modification by certain antiinflamatory drugs. J Pharmacol Exp Ther 183: 226-234.

Tyler VE, Brady LR, Robbers JE, 1988. Pharmacognosy. Lea \& Febriger, Philadelphia, PA.

Vonkerman HE, Van de Laar MAFJ 2008. Nonsteroidal antiinflammatory drugs: adverse effects and their prevention. Semin Arthritis Rheu 39: 294-312.

Winter CA, Risley EA, Nuss GW 1962. Carrageenan induced edema in hind paw of rat as an assay for anti-inflammatory drugs. Prog Soc Biol Med 11: 544-547.

Yedgar S, Cohen Y, Shoseyov D 2006. Control of phospholipase A2 activities for the treatment of inflammatory conditions. Biochim Biophys Acta 1761: 1373-1382.

Yoshiki Y, Takagi S, Watanabe M, Okubo K 2005. Fractionation of soybean functional glycosides from soy-waste based on the chemical reaction of soyasaponin $\mathrm{Bg}$. Food Chem 93: 591-597.

Young JM, De Young LM 1989. Cutaneous models of inflammation for the evaluation of topical and systemic pharmacological agents. In: Chang JY, Lewis AJ, eds. Pharmacological Methods in the Control of Inflammation. New York: Alan R. Liss, p. 215-231. 